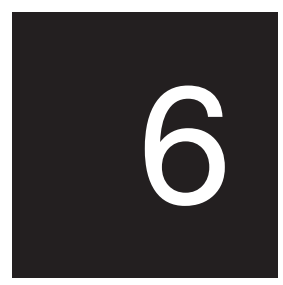

\title{
Rumble in the jungle: land, culture and (un)sustainable logging in Solomon Islands
}

\section{Tarcisius Tara Kabutaulaka}

As a landowner from Malaita gulped down the Solbrew to quench his thirst, with a sigh of relief he made it clear where the money came from to finance his favourite pastime: Lif blong akwa nomoa tok (it's the leaf of the akwa tree that talks). In another incident, a Guadalcanal man who went on a drinking spree with his son told him: Inu ko inu dalequ, inau a lani ona (drink, drink my son, I'm a landowner). I recount these incidents not because there is any particular connection between logging in Solomon Islands and the beer company Solbrew. Rather, the statements demonstrate the ties between land, forest resources, landowners and the kinship bond between people. It signifies the power landowners have, or at least think they have, over resources such as forest.

I have chosen alcohol and drinking-a substance and an activity which are normally found far from rain forests, logging trucks and chainsaws - as the starting point around which to build my exploration of the relationship between land, culture and logging. It illustrates that in the process of resource exploitation and increasing commercialisation, there is also a process of cultural construction and deconstruction taking place. The eventual product is a hybrid culture which has a profound impact on the issue of sustainable forest management. In this case, the beer shifts from the bar and home to the 
forest. In some instances, the alcohol becomes the commodity around which the logging industry revolves-it dictates the nature of logging negotiations, state policies, and the relationship between landowners and the different stakeholders in the forest industry. This affects sustainability. It is when this happens that the rumble in the jungle begins.

Sustainable logging in Solomon Islands has been difficult, not only because of poor state policies, but also because (i) the land tenure system, and (ii) the logging industry, produce a culture characterised by the rapid monetisation of certain sectors of society, increasing corruption at the political level, and the emergence of a new élite group in the villages. This new élite group is nearly always financed by logging money and backed by logging companies.

\section{Logging and cultural production}

An old man from Guadalcanal once said to me: logging hemi spoelem ples en kastom blong iumi 'logging spoils our place and custom'. Implicit in this statement is the conception of culture, not only as rules, norms or customs that regulate society, but also as the social and physical environment around which culture is produced and sustained through time. The forest, therefore, is not just an economic commodity with the potential of generating monetary income. Rather, it is part of the physical and social existence of society.

Antony Hooper, in discussing the sociocultural aspects of development in the South Pacific, defines culture as 'the body of shared understandings in terms of which social interactions take place' (1993:315). Culture also includes the means by which shared understandings are produced and sustained through time. Tradition, on the other hand, is used here to refer to a model of a past way of life. It does not imply something which has existed unchanged since contact with the outside world, even though it is sometimes represented as being unchanging. Rather, the term is used here to refer to the sets of social behaviour and 'ways of doing things' that have emerged, and continue to have a connection to the past. According to Erchak, 'culture is shared symbolic knowledge which people draw on as they make their way through life. It provides its bearers pathways to a satisfying life-or at least survival' (1992:3). This is a useful definition when discussing the impact of large-scale resource exploitation on society, and the production of a hybrid culture which often has a significant 
impact on both the industry and society. In nearly all large-scale resource development projects such as mining, forest and fisheries, there are usually a number of stakeholders involved. Often, the most dominant are the state, multinational companies, landowners, nongovernment organisations, politicians, and local entrepreneurs. These stakeholders usually have different interests in participating in an industry such as forestry. Each stakeholder attempts to maximise its monetary benefit from the resource at stake. In such a situation, 'the body of shared understandings' is usually embodied in the contract signed between the stakeholders. This contract is, in nearly every case, surrounded by a culture of intense competition between stakeholders which often is subsequently accepted as the norm.

\section{Logging in Solomon Islands: a background}

In the past ten years, logging in Solomon Islands has attracted considerable debate, both nationally and internationally. The discussions have centred around (i) the unsustainable rate of log harvests; (ii) the country's increasing economic dependence on log exports; and (iii) allegations of corruption-especially in relation to politicians and public officers receiving bribes from logging companies.

Large-scale commercial logging started in Solomon Islands over thirty years ago. From 1963 to the early 1980s most logging took place on government land or customary land leased by the government, and the industry was then monopolised by Levers Pacific Timber, which accounted for around 75 per cent of log production. However, from the early 1980s there was a shift from government land to customary land (which makes up around 87 per cent of the total land area in the country). This period was also characterised by an influx of logging industry multinationals, mostly from Southeast Asia. During the period from 1981 to 1983, the number of logging licences given to foreign companies increased fourfold (Fraser 1997:41). This sets to rest the argument that communally-owned land or customary land is less likely to guarantee security of access, and therefore less likely to attract foreign investors. The fact that foreign logging companies swamped Solomon Islands at a time when logging was mostly on customary land is an indication that they have established a means of acquiring 'security of access' and maintaining it for a period long enough for them to accumulate substantial profit.

The increase in the number of logging licenses issued to foreign companies resulted in a rapid increase in log production, and by 1981 
it had gone beyond sustainable levels (Fraser 1997:42; Montgomery 1995:75). By the mid 1990s timber was being exploited at a rate that significantly exceeded the potential sustainable yield, which in 1995 was about 325,000 cubic metres per year (Solomon Islands Government 1995). Log exports in 1994 and 1995, for example, were 659,000 and 748,500 cubic metres respectively (Central Bank of Solomon Islands 1996:16). This was more than double the potential sustainable yield at that time. Consequently, it has been estimated that if current levels of $\log$ production continue, commercial trees may be depleted in less than a decade (Fraser 1997:51; Dauvergne 1997:6).

The increasing log production was exacerbated by the fact that by the beginning of the 1990s Solomon Islands had become economically almost entirely dependent on logging. In 1990, for example, timber contributed 34.5 per cent of the country's total exports. This increased to 54.9 per cent in 1993. In 1994, it contributed 56 per cent of the country's export revenue and 31 per cent of all government revenues (Montgomery 1995; Fraser 1997). In 1995 it made up for 49.4 per cent of principal exports (Central Bank of Solomon Islands 1996:16).

Furthermore, insufficient finance, and the lack of technical and human resources to monitor logging operations has meant that it is difficult to implement state forest policies, and in particular environmental rules. Consequently, many multinationals in the industry break the regulations and get away with it. The Solomon Islands Division of Inland Revenue, for example, does not have the financial, technical and manpower capability to prevent or counteract corporate schemes to evade taxes (Price Waterhouse 1995:78).

Dauvergne also noted that structural defects in Solomon Islands' forest management policies have enabled 'multinational investors to operate with remarkably poor harvesting and environmental standards, and make windfall profits' (1997:8). The problem was further exacerbated by the withdrawal in 1996 of the AusAID-funded Timber Control Unit. This unit, set up to monitor logging operations and the activities of corporate powers, had its funding withdrawn after relations between the Solomon Mamaloni-led government and the Australian government went sour (Solomon Star, 2 April 1996). This means that Solomon Islands lost out on millions of dollars worth of potential income from forestry. Further potential income was lost because of government policy to exempt some logging companies from paying export tax. In 1994 it was estimated that SI\$34 million was lost through the government's decision to exempt some logging companies from paying 
export tax (Duncan 1994:10). This was particularly the case for 'locally owned' companies such as the Prime Minister's own Somma Ltd. Also, under-reporting of log volumes is estimated to have cost Solomon Islands SI\$96 million in revenues evaded and foregone in 1993 (Duncan 1994:16). It is these situations in the forest industry that have raised widespread alarm both locally and internationally. However, so far, the campaign to slow down the rate of logging has been unsuccessful. Unsustainable logging continues unabated.

Hence, one is confronted with the questions (i) why is it that the unsustainable logging continues unabated despite evidence of its negative environmental, social and economic impact on Solomon Islands? and (ii) what is/are the solution(s)? So far, most literature on logging in Solomon Islands is either historical (Bennett 1995), or focuses on discussing forest as an economic commodity (Duncan 1994; Montgomery 1995). This is not surprising given that the logging industry was indeed viewed by the state and others as a resource of economic value to the country. However, the problem with such an emphasis on the economics of forestry is that often it fails to acknowledge the social factors that influence people's decisions. It is, therefore, necessary to discuss (i) the impact of land tenure on sustainable forest management and (ii) how social organisations affect decision-making on logging.

\section{Land tenure and logging}

Ballard, in discussing the moral economy of resource ownership in Papua New Guinea states that

...for those of us for whom ties to land consist of casual contacts with small and often infrequently tended suburban gardens, one of the more difficult exercises in imagination is to conceive of the relationship between rural communities and the lands and the resources that they consider theirs (1997:47).

Often this is also a problem for policymakers for whom land and the resources on it are primarily economic commodities-to bring in much needed monetary income for state wealth — and only secondarily as part of an environment around which a society constructs its culture and lives its life.

In Solomon Islands land-based resource developments such as logging and mining are usually influenced by a land tenure system where about 87 per cent of the land is owned according to custom, 
leaving only about nine per cent to government ownership and the rest to individual Solomon Islanders. Only two per cent of the land is leased to foreigners. However, what is important to consider in the relationship between logging and land tenure is the nature of the politics of land ownership, the interactions within and between landowning groups that has affected, and been affected by, the logging industry.

Today, logging and land disputes are interrelated. Many logging companies come to Solomon Islands from Southeast Asia, especially from Indonesia and Malaysia where the state owns the land. Hence, they find it much easier to deal with the state or individuals rather than the tribe or clan. Consequently, they create individual landowners. On the island of Rendova, in the Western Province, for example, I found an individual who had left a job in the public service to become a full-time 'landowner' because, with logging companies around, it is a much more financially lucrative profession. In such a situation, the tribe is usually marginalised and denied access to the wealth accumulated through logging.

There are also cases where the state has found itself at the centre of land disputes. A classic example is the case of Pavuvu in the Russell Islands in the Central Province. Here, the British colonial government in 1905 leased Pavuvu Island to Levers Pacific Plantations. The original owners of the island, the Lavukal people of the Russell Islands had, for many years, demanded that the island be restored to them. However, their demands were ignored (Rose 1995:10). On 10 March 1995, the executive of Central Province granted Marving Brothers, a Malaysian registered logging company, a business license that allowed the central government to issue a logging permit for Pavuvu Island. The island's forest was worth about US\$120 million (Roughan 1997:160). The Lavukal people, assisted by non-government organisations such as the Solomon Islands Development Trust (SIDT), Soltrust, Greenpeace and Development Services Exchange (DSE) resisted the logging of Pavuvu. Company machines were sabotaged and workers were threatened. However, the central government sent in police officers to protect the company that is currently still logging on 'government land' (Roughan 1997; Tuhanuku 1995). Today, Pavuvu Island is still at the centre of intense confrontation between landowners, the central government, Central Province and Marving Brothers. In November 1995, Martin Apa, a Russell Island anti-logging campaigner, was murdered. So far police 
investigations have failed to find his killers although many suspect that the murder was connected to the Pavuvu Island logging issue.

This is only one example of land and boundaries disputes over that are now common throughout Solomon Islands, and particularly in areas where there are large-scale resource developments such as logging, mining, and plantation development. There's a need to take landowners and traditional land tenure systems seriously when planning national development programs. The large percentage of customary control of land also has implications for the state's capacity to manage land-based resource developments. One of the major arguments in the logging industry is that the government in reality does not have control over landowners' decisions to exploit the forest resource in the way they wish. In the case of the forestry industry, first, it signifies the fact that in Solomon Islands the state is weak in comparison to civil society (Kabutaulaka and Dauvergne 1997). The state does not possess the kind of power and authority over society that one would find in, for example, the hierarchical chiefly system of Tonga. Second, the nature of current logging practices in Solomon Islands indicates that 'people's' control over resources does not necessarily mean that it will be well managed. In fact, the case of forestry in Solomon Islands proves the opposite.

Another factor that characterises the relationship between logging and land tenure is the alienation of women, not only as land users, but as custodians of land. In the matrilineal societies of Guadalcanal, Ysabel and Roviana (on New Georgia island) women traditionally had authority as custodians of land. However, throughout Solomon Islands I have not yet found a logging agreement in which women have been included as signatories. This is because men have always been promoted as landowners and income earners.

\section{Logging and a political culture}

In Solomon Islands, logging has given rise to a political culture often characterised by the increasing participation of state leaders in the forest industry, and the adoption by state leaders of a double identity, as state leaders and landowners-a kind of schizophrenic professional commitment. The most well known of these state leaders was the former Prime Minister who owns a logging company, Somma Ltd. His company also enjoys a 100 per cent export tax exemption on round log exports. It is interesting that in August 1998, when I asked the then 
Finance Minister why he awarded a tax exemption to the Prime Minister, he replied that he did not give it to the Prime Minister, but to a landowner.

Corruption has also been widespread in the logging industry, from the village level to the highest offices of the state. In November 1995, five government ministers were alleged to have received SI $\$ 7$ million in bribery money from a logging company and this has resulted in court proceedings which are currently under way (Solomon Star, 19 November 1995). In another case, two government ministers were charged with receiving favours from Marving Brothers, the logging company involved in the controversial Pavuvu logging disputes. In 1995, a local newspaper, the Solomon Star, reported that an accountancy firm had uncovered an internal report that a Malaysian company had paid SI\$17 million to government ministers and officials, and named the then Minister for Commerce, Employment and Trade, the Minister for Finance and the Minister for Home Affairs, as well as the former secretary to the Foreign Investment Board (Pacific Report 8(21) November 20,1995). The Ombudsman cited the funding of election expenses by timber companies and evidence that members of Area Councils deciding on applications from logging companies were given 'Negotiation Fees', employment and hotel stays when in Honiara (Solomon Islands 1989:10-11). There is also increasing concern over the distribution of logging revenues and whether it has contributed to socioeconomic development in the country.

Corruption in the forest industry has become a major concern in Solomon Islands today. The concern centres around the fact that corruption may become the culture of the forest industry. There are fears that we may reach a situation where we can no longer talk about getting rid of corruption from the system because it may become the system.

For politicians, what is regarded as corruption in the conventional sense is, in fact, the essence of survival. In a society where a Bigman's wealth is measured, not so much in what he accumulates as in what he distributes, it is important that a Bigman finds a means of acquiring wealth for distribution. Logging provides that means. A politician needs the logging money in order to stay in power. This is because of the nature of patron/client relationships that characterise our traditional culture-a norm that has suddenly been labelled as corruption. Wealth accumulated and kept. 


\section{Conclusion}

What is obvious from the case of logging in Solomon Islands is that in large-scale resource exploitation there is a continuous process of cultural construction and deconstruction. These have an important impact on sustainable forest management-the ability to maintain the forest's capacity to produce timber at a specified rate. The concern is the maintenance of sufficient stocks to last for a defined period of time. It is conspicuous that in order to address the issue of sustainable forest management, there is a need to be aware of the sociocultural factors that influence decisions on forest development. For now, the rumbles in our jungles continue.

\section{References}

Ballard, C., 1997. 'It's the land stupid!: the moral economy of resource ownership in Papua New Guinea', in P. Lamour (ed.), The Governance of Common Property in the Pacific Region, National Centre for Development Studies and Resource Management in Asia-Pacific, Research School of Pacific and Asian Studies, The Australian National University, Canberra:47-65.

Bennett, J., 1995, 'Forestry, public land and the colonial legacy in Solomon Islands', The Contemporary Pacific, 7(2):243-75.

Central Bank of Solomon Islands, 1996. 1995 Annual Report, Central Bank of Solomon Islands, Honiara.

Dauvergne, P., 1997. Corporate Power in the Forests of the Solomon Islands, Working Paper 1997/6, Department of International Relations, Research School of Pacific and Asian Studies, The Australian National University, Canberra.

Duncan, R.C., 1994. Melanesian Forestry Sector Study, International Development Issues No.36, Australian International Development Assistance Bureau, Canberra.

Erchak, G.M., 1992. The Anthropology of Self and Behaviour, Rutgers University Press, New Jersey.

Fraser, I., 1997. 'The struggle for control of Solomon Island forests', The Contemporary Pacific, 9(1):39-72.

Hooper, A., 1993. 'Socio-cultural aspects of development in the South Pacific', in R.V. Cole and S. Tambunlertchai (eds), The Future of AsiaPacific Economies: Pacific islands at the crossroads? Asian and Pacific Development Centre and National Centre for Development Studies, The Australian National University, Canberra:314-42. 
Kabutaulaka, T.T. and Dauvergne, P., 1997. 'The weak state in Solomon Islands', paper presented at the workshop entitled Weak and Strong States in Melanesia and Southeast Asia, 12-14 August, 1997, Research School of Pacific and Asian Studies, The Australian National University, Canberra.

Migdal, J., 1988. Strong Societies and Weak States: state-society relations and state capabilities in the third world, Princeton University Press, Princeton.

Montgomery, P., 1995. 'Forestry in Solomon Islands', Pacific Economic Bulletin, 10(2):74-76.

Price Waterhouse, 1995. Forestry, Taxation, and Domestic Processing Study, Consultancy Report for the Solomon Islands Government, Ministry of Finance and the Ministry of Forests, Environment and Conservation.

Rose, A., 1995. Petition of the Lavakal People to the Solomon Islands Government, Privately published, Honiara.

Roughan, J., 1997. 'Solomon Islands nongovernment organizations: major environmental actors', The Contemporary Pacific, 9(1):157-166.

Solomon Islands Government, 1995. Forest Review, Ministry of Forests, Environment and Conservation, Honiara.

Tuhanuku, J., 1995. Report of the Opposition Delegation Mission to Pavuvu, Office of the Leader of the Opposition, Honiara. 